\title{
Revisión | Review \\ Medicinal plants as a source of future anti-pruritic drugs: A comprehensive review
}

\author{
[Las plantas medicinales como fuente de futuros fármacos antipruríticos: una revisión exhaustiva] \\ Fahimeh Mohajerani ${ }^{1}$, Mannan Hajimahmoodi ${ }^{2}$, Laila Shirbeigi $^{3}$ \& Roja Rahimi $^{1,4}$ \\ ${ }^{1}$ Department of Traditional Pharmacy, School of Persian Medicine, Tehran University of Medical Sciences, Tehran, Iran \\ ${ }^{2}$ Department of Drug and Food Control, Faculty of Pharmacy, Tehran University of Medical Sciences, Tehran, Iran \\ ${ }^{3}$ Department of Persian Medicine, School of Persian Medicine, Tehran University of Medical Sciences, Tehran, Iran \\ ${ }^{4}$ Evidence-Based Medicine Group, Pharmaceutical Sciences Research Center, Tehran University of Medical Sciences, Tehran, Iran \\ Contactos | Contacts: Roja Rahimi - E-mail address: rojarahimi@gmail.com
}

\begin{abstract}
Pruritus is a distressing sensation of the skin that provokes the desire to scratch. Medicinal plants have been proposed as a worthful source for identifying new bioactive molecules. The aim of this study was to evaluate some medicinal plants and their phytochemicals used in the management of pruritus. Medicinal plants including Avena sativa, Borago officinalis, Capsicum frutescens, Curcuma longa, Fumaria spp., Mentha x piperita and Oenothera biennis showed the promising anti-pruritic activity in human studies. In experimental studies, Angelica sinensis, Betula platyphylla, Matricaria chamomilla, Rumex Japonicus, Saururus chinensis and Vaccinium myrtillus are among the best medicinal plants for management of pruritus. Essential oils, alkaloids, saponins, sterols, terpens, phenolic compounds, and fatty acids were the bioactive constituents of herbs which exhibited their anti-pruritic activity through different mechanisms. The most predominant mechanisms involved in activity of plant-derived molecules in pruritis include reducing serum IgE and proinflammatory cytokines, stabilizing mast cells, suppressing the Th2 cellular response, suppressing the expression of substance $\mathrm{P}$ and NF$\kappa \mathrm{B}$, inhibiting prostaglandin E2 production, and activating receptors involved in itch sensation. Overall, several medicinal plants and its bioactive compounds have shown marked activity in the management of pruritus and therefore can be considered as an alternative source of treatment.
\end{abstract}

Keywords: Itch; Pruritus; Plant; Scratch; Herbal medicine; Phytochemical

Resumen: El prurito es una sensación molesta en la piel que provoca el deseo de rascarse. Las plantas medicinales han sido propuestas como una fuente valiosa para identificar nuevas moléculas bioactivas. El objetivo de este estudio fue evaluar algunas plantas medicinales y sus fitoquímicos en el manejo del prurito. Plantas medicinales que incluyen Avena sativa, Borago officinalis, Capsicum frutescens, Curcuma longa, Fumaria spp., Mentha x piperita y Oenothera biennis mostraron una prometedora actividad antiprurítica en estudios humanos. En estudios experimentales, Angelica sinensis, Betula platyphylla, Matricaria chamomilla, Rumex Japonicus, Saururus chinensis y Vaccinium myrtillus se encuentran entre las mejores plantas medicinales para el manejo del prurito. Los aceites esenciales, alcaloides, saponinas, esteroles, terpenos, compuestos fenólicos y ácidos grasos fueron los constituyentes bioactivos de las hierbas que mostraron actividad antiprurítica a través de diferentes mecanismos. Los mecanismos más predominantes implicados en la actividad de las moléculas derivadas de plantas en el prurito incluyen la reducción de la IgE sérica y las citoquinas proinflamatorias, la estabilización de los mastocitos, la supresión de la respuesta celular Th2, la supresión de la expresión de la sustancia $\mathrm{P}$ y $\mathrm{NF}-\kappa \mathrm{B}$, la inhibición de la producción de prostaglandina E2 y la activación de receptores implicados en la sensación de picazón. En general, varias plantas medicinales y sus compuestos bioactivos han mostrado una actividad efectiva en el manejo del prurito y, por lo tanto, pueden ser consideradas como una fuente alternativa para su tratamiento.

Palabras clave: Picazón; Prurito; Planta; Rascarse; Medicina herbaria; Fitoquímico

Recibido | Received: December 4, 2018

Aceptado | Accepted: December 15, 2018

Aceptado en versión corregida | Accepted in revised form: December 21, 2018

Publicado en línea | Published online: January 30, 2019

Este artículo puede ser citado como / This article must be cited as: F Mohajerani, M Hajimahmoodi, L Shirbeigi, R Rahimi. 2019 Medicinal plants as a source of future antipruritic drugs: A comprehensive review. Bol Latinoam Caribe Plant Med Aromat 18 (1): 1 - 15. Https://doi.org/10.35588/blacpma.19.18.1.01 


\section{LIST OF ABBREVIATIONS}

AD: Atopic dermatitis; CU: Chronic urticaria; CUQ2oL: Chronic urticaria quality of life questionnaire; DNCB: 2, 4-dinitrochlorobenzene; hs-CRP: highsensitivity $\mathrm{C}$-reactive protein; IFN- $\gamma$ : Interferon gamma; IgE: Immunoglobulin E; IL: Interleukin; NF$\kappa \mathrm{B}$ : Nuclear factor-kappa light-chain enhancer of activated B cells; PG102: A general term for various preparations from Actinidia arguta; PG102E: Ethylacetate-soluble fraction from PG102T; PG102T: Total water-soluble extract from Actinidia arguta; QoL: quality of life; SP: Substance P; $\mathrm{T}_{\mathrm{h}} 2$ : T-helper cell type 2; TNF- $\alpha$ : Tumor necrosis factor alpha; TRPM8: Transient receptor potential cation channel, subfamily M, member 8; TRPV1: Transient receptor potential vanilloid 1; UAS: Urticaria activity score.

\section{INTRODUCTION}

Skin disorders are one of the most common health problems among people, causing emotional and psychological stress. These disorders account for approximately $34 \%$ of all occupational diseases encountered worldwide (Goyal et al., 2014; Maurya \& Seth, 2014). Pruritus or itch is an irritating and unpleasant sensation which produces a desire of scratching. Chronic itching can be severe enough to cause negative interference with many aspects of life. In addition, induced scratching behavior often leads to secondary lesions which can be followed by cutaneous infections (Ikoma et al., 2006).

Data on the prevalence of pruritus demonstrated 8-9\% people experienced acute pruritis during their life (Rea et al., 1976; Dalgard et al., 2004). Recent studies showed higher prevalence of pruritis even around $13.5 \%$ in the general adult population (Dalgard et al., 2007; Matterne et al., 2011). Despite the high prevalence of pruritus, it has not received much attention until recently (Goyal et al., 2014; Maurya \& Seth, 2014).

Pruritus has various etiologies and pathophysiologies. It can be as a characteristic feature of numerous skin diseases or as an unusual sign of certain systemic and neurological diseases. It can also arise from dry skin, especially in cold winter months. Pruritus may be localized or generalized and can occur both acutely and chronically. Localized pruritus appears in the skin disorders especially in deffirent types of dermatitis. Generalized pruritus may be consequence of environmental factors including low humidity, skin diseases such as urticaria, or internal diseases including biliary obstruction, renal failure, hematologic malignancy or acquired immunodeficiency syndrome (Sänder et al., 2007). Extreme pruritus often results in secondary lesions such as erythema, erosions and crusts, followed by cutaneous infections (Waisshaar et al., 2003).

\section{Pathophysiology of Pruritus}

Various pathological processes are involved in pruritus: inflammation, hypersensitivity, degenerative changes, malignant tumors, and even psychic abnormalities (Goyal et al., 2014). Neurophysiological experiments in humans and animals have exhibited that itch is carried by specific C nerve fibers (Yosipovitch \& Fleischer, 2003). The sensation of itch is transmitted through specific peripheral unmyelinated $\mathrm{C}$-fiber nerves in which are located in the epidermis and dermis. These neurons are located more superficially and are more sensitive to pruritogenic substances (Goyal et al., 2014). These $\mathrm{C}$-fiber nerves also called pruriceptors are a subclass of C-nociceptors for pain, but functionally different from pain fibers (Twycross et al., 2003). The symptom of itch occurs when free nerve endings of the specialized C-fibers are stimulated by pruritogenic substances.

A number of endogenous and exogenous pruritogens (itch triggers) have been identified. The pruritogenic mediators are mentioned in Table No. 1. Furthermore, other endogenous pruritogens and different exogenous pruritogens and also their mechanisms of action are mentioned in Table No. 2 and Table No. 3, respectively.

\section{Management/Treatment of Pruritus}

Anti-pruritic strategy could be assigned according to the underlying causes of different categories of itch (Yosipovitch \& Fleischer, 2003). Treatment options include non-pharmacological and pharmacological measures (Goyal et al., 2014). Non-pharmacological treatments include life style modifications and diet. Pharmacological strategies consist of topical and systemic treatments.

\section{Topical Therapy}

Topical therapies contain emollients, topical corticosteroids, and Topical calcineurin inhibitors. 
Table No. 1

Different pruritogenic mechanisms of mediators

\begin{tabular}{|l|l|l|}
\hline Mediators & Site of release & Pruritogenic mechanism \\
\hline Histamine & $\begin{array}{l}\text { Histamine H1 } \\
\text { receptor }\end{array}$ & Activating the cutaneous C-fibres \\
\hline $\begin{array}{l}\text { Acetylcholine } \\
\text { (neurotransmitter) }\end{array}$ & $\begin{array}{l}\text { Muscarinic and } \\
\text { nicotinergic } \\
\text { receptors }\end{array}$ & $\begin{array}{l}\text { Causes itch only in atopic persons (but not in } \\
\text { non-atopic persons) }\end{array}$ \\
\hline $\begin{array}{l}\text { Serotonin (a mediator in } \\
\text { psychogenic itch) }\end{array}$ & 5-HT3 receptors & A potent activator of unmyelinated C-fibres \\
\hline Bradykinin & - & $\begin{array}{l}\text { Induces mast-cell degranulation for the } \\
\text { release of histamine and enhances histamine } \\
\text { responses }\end{array}$ \\
\hline Prostaglandins & $\begin{array}{l}\text { Potentiate histamine-induced itch by lowering } \\
\text { the receptor threshold to histamine and } \\
\text { papain }\end{array}$ \\
\hline $\begin{array}{l}\text { Cytokines: Interleukins } \\
\text { (IL-2, IL-4, IL-6 and IL-31) }\end{array}$ & $\begin{array}{l}\text { T cells and } \\
\text { macrophages }\end{array}$ & Activating the cutaneous C-fibres \\
\hline
\end{tabular}

Table No. 2

Endogenous pruritogens and their mechanisms of action

\begin{tabular}{|l|l|}
\hline Endogenous pruritogen & Pruritogenic mechanism \\
\hline Nerve growth factor & Sensitization of peripheral nerve fibers \\
\hline $\begin{array}{l}\text { Substance P (SP), Calcitonin } \\
\text { gene-related peptide (CGRP) }\end{array}$ & $\begin{array}{l}\text { Acute pro-inflammatory reactions including vasodilatation } \\
\text { and protein extravasation, trophic function and } \\
\text { immunomodulation }\end{array}$ \\
\hline $\begin{array}{l}\text { Endogenous opioids: } \\
\text { enkephalin, } \beta \text { - endorphin } \\
\text { (through stimulation of mu } \\
\text { receptors) }\end{array}$ & $\begin{array}{l}\text { Modulation the sensation of pruritus both centrally and } \\
\text { peripherally }\end{array}$ \\
\hline Stress & $\begin{array}{l}\text { Modification of expressing the inflammatory cytokines by } \\
\text { mast cells }\end{array}$ \\
\hline
\end{tabular}

\section{Systemic Therapy}

Systemic therapies include antihistamines, systemic corticosterioids, immunomodulators, interferon gamma, monoclonal antibodies, and immunosuppresants.

However inadequate efficacy, high rate of recurrence and the suppression of immune system, and hepatic and renal toxicity have limited their use in the treatment of this syndrome. Hence, the management of pruritic conditions remains a therapeutic challenge due to its multifactorial etiology and complex pathophysiology (Goyal et al., 2014; Maurya \& Seth, 2014).

\section{Prospect}

The use of medicinal plants as complementary or alternative strategy for management of diseases especially chronic conditions is arising (Farzaei et al., 
2013; Mobli et al., 2015). Plant-derived compounds or phytochemicals are assumed as an invaluable source for discovering new pharmaceutical agents (Farzaei et al., 2016a; Farzaei et al., 2016b; Shahpiri et al., 2016).

\section{Purpose of the Present Study}

The aim of present study is to comprehensively review medicinal plants with well-established activities in pruritus and discuss their possible underlying mechanisms.

Table No. 3

Different Exogenous Pruritogens

\begin{tabular}{|l|l|}
\hline Chemical stimuli & Physical stimuli \\
\hline $\begin{array}{l}\text { Botanicals: poison ivy, stinging nettles, and } \\
\text { cowhage spicules }\end{array}$ & Light touch, pressure, and suction \\
\hline Latex (a plant derivative) & Heat \\
\hline Cosmetics and soaps & Electrical stimulation \\
\hline Insect bites & Wool fibers \\
\hline Parasite infestations (ie, scabies) & Fiberglass \\
\hline Drugs: opiates, aspirin, and $\beta$-blockers & Water (“aquagenic pruritus") \\
\hline Chemical stimuli & Physical stimuli \\
\hline
\end{tabular}

\section{Research method}

In this article it has been focused on the use of medicinal plants in various dermatological conditions characterized by pruritus. For this purpose, online searches were conducted in electronic databases including English-language papers published up to 2018 in PubMed, MEDLINE, Scopus, Google Scholar, Science Direct and reference lists of retrieved articles from 1960s to 2018 (up to May) for any in vitro, animal or clinical studies investigating the efficacy of a medicinal plant or its bioactive component in managing of pruritus. The searched keywords were "plant", "herb", "extract", "itch", "pruritus", "scratch" and "anti-pruritic". The title and abstract of each article were examined to eliminate duplicates.

\section{Anti-pruritic medicinal plants and their bioactive components for managing pruritus}

The medicinal plants studied in this review are arranged alphabetically according to their scientific name, followed by family name, parts used, growing area, related clinical trials, main bioactive components, and probable mechanism of anti-pruritic effect.

\section{Aloe vera}

Aloe vera (L.) Burm.f. commonly known as Aloe vera (Family: Xanthorrhoeaceae) is a shrub originated in the Sudan and the Arabian Peninsula and is now found in various regions of the world
(Fleming, 2000). A study investigating the effects of oral Aloe vera gel (AV) on atopic dermatitis mice with the symptoms like itching demonstrated relief in $\mathrm{AD}$ due to reduction of interleukin (IL)-5 and IL-10 levels (Kim et al., 2010). In a double-blind placebocontrolled study, 60 patients with mild to moderate plaque psoriasis were topically treated with either $0.5 \%$ hydrophilic Aloe cream or placebo. The Aloetreated group showed marked improvement $(83.3 \%)$ compared to the placebo group (6.6\%). No adverse events were reported in the treatment group (Syed et al., 1996). Inhibition of Cox-2 and thromboxanes by aloesin was revealed in vitro (Yagi et al., 2002). A topical mixture of $A$. ferox and $A$. vera extracts decreased the serum level of $\operatorname{IgE}$ in an atopic dermatitis mouse model (Finberg et al., 2015). Fresh Aloe vera Gel significantly reduced acute inflammation in rats (carrageenan-induced paw edema). The anti-inflammatory effect of the Aloe gel has been related to its enzymes, carbohydrates and sterols contents. Bradykinase inhibited thromboxane $\mathrm{B}_{2}$ and prostaglandin $\mathrm{F}_{2}$ activity in vitro, and mannose-6-phosphate, acemannan and sterols (mainly lupeol) reduced inflammation in vivo (Choi \& Chung, 2003).

\section{Actinidia arguta}

Actinidia arguta (Siebold \& Zucc.) Planch. Ex Miq. with the common name of Hardy Kiwi (Family: Actinidiaceae) is a perennial plant native to eastern Asia and Russian Siberia (Park et al., 2007). 
Administration of oral formulas from Actinidia arguta significantly decreased dermatitis severity and scratching tendency in NC mice through reducing plasma level of selective $\mathrm{T}_{\mathrm{H}} 2$ cytokines, $\operatorname{IgE}, \operatorname{IgG}_{1}$ and IL-4 (Park et al., 2005; Park et al., 2007).

\section{Amorphophallus konjac}

Amorphophallus konjac commonly named Konjac (Family: Araceae) is a plant found in eastern Asia which has an edible corm and is commonly used in Japan as cooking supplement. Konjac Glucomannan, a dietary fiber isolated from the tubers of Amorphophallus konjac, is a highly viscous polysaccharide composed of glucose and mannose residues. Consuming Konjac Glucomannan by $\mathrm{NC} / \mathrm{Nga}$ mouse model reduced the severity of skin symptoms including scratching behavior, suppressed $\mathrm{IgE}$ production and substance-p expression and decreased total Immunoglobulin, as well as markedly reduced skin inflammatory immune response related to IL-4, IL-10, TNF- $\alpha$, and IFN- $\gamma$ (Onishi et al., 2004; Onishi et al., 2005; Onishi et al., 2007).

\section{Angelica sinensis}

Angelica sinensis (Oliv.) Diels commonly known as Dong quai (Family: Apiaceae) is an herb indigenous to eastern Asia. The topical application of Dong quai to mice with atopic dermatitis inhibited progression of scratching behavior and substance-p expression as wells as reduced the number of mast cells, and the level of serum IgE. Moreover, it reduced the level of cytokines (IL-4, IL-6, TNF- $\alpha$, and IFN- $\gamma$ ) as well as the expressions of NF- $\mathrm{KB}$ in the dorsal skin (Lee et al., 2016).

\section{Avena sativa}

Avena sativa $\mathrm{L}$. with the common name of Oat (Family: Poaceae) is a light-green annual grass originated in European regions, and are now cultivated worldwide (Fleming, 2000). In a controlled clinical study, administration of a body lotion containing colloidal oatmeal (oat flour), oat extract, oat oil and a skin protectant to extra-dry, itchy skin demonstrated significant improvement in alleviating itch (Nebus et al., 2006). In another study involved 29 women with moderate or severe dry skin on their lower legs, associated with chronic mild or moderate itching. substantial improvement in dryness and itching was reported after topical administration of colloidal oat meal (Nebus \& Wallo, 2008). Colloidal oatmeal extracts reduced pro-inflammatory cytokines in vitro (Reynertson et al., 2015). In a study, topical application of avenanthramides, a group of phenolic alkaloids present in Oat, reduced pruritogen-induced scratching in a murine itch model (Sur et al., 2008).

\section{Betula platyphylla}

Betula platyphylla Sukat. var. japonica Hara commonly named Asian white birch (Family: Betulaceae) is a thin-leaved deciduous hard-wood tree which grows in Korea and Japan. The bark of Asian white birch has been used in Eastern countries for the treatment of a variety of inflammatory disorders including atopic dermatitis (Alakurtti et al., 2006). Oral administration of Asian white birch extract significantly suppressed scratching behavior and skin inflammation through decreasing $\operatorname{IgE}$ and IL-4 messenger ribonucleic acid (mRNA) serum levels in mice model of atopic dermatitis, suggesting that it suppresses the $\mathrm{T}_{\mathrm{h}} 2$ cellular response (Kim et al., 2008).

\section{Borago officinalis}

Borago officinalis L. with the common name of Borage (Family: Boraginaceae) is an annual, succulent, bristly-haired herb which is found all over Europe and the USA. (Fleming, 2000). In a doubleblind, placebo-controlled study, Borage oil-coated undershirts were given to 32 children with atopic dermatitis. After 2 weeks, a marked improvement was demonstrated in symptoms of itch and erythema (Kanehara et al., 2007). The results of a clinical study demonstrated that modest doses of GLA ( $\Upsilon$-linolenic acid) produced clinical improvement in the symptoms of atopic dermatitis disease, particularly in itching (Stewart et al., 1991). Borage oil contains a high content (24\%) of $\Upsilon$-linolenic acid (GLA) which possessing remarkable anti-inflammatory activity (Horrobin, 2000).

\section{Bulgaria inquinans}

Bulgaria inquinans (Pers.) Fr. commonly known as Black bulgar (Family: Bulgariaceae) is a woodinhibiting ascomycete growing on freshly felled oak and widely distributed in Northeastern China. The ethanol extract of Black bulgar dose-dependently inhibited scratching behavior induced by compound 48/80 and serotonin in ICR mice and also showed a powerful inhibitory effect on histamine release induced by compound 48/80 (Jiang et al., 2005).

\section{Cannabis spp.}

Cannabis spp. with the common name of Hemp (Family: Cannabaceae) are annual or biennial plants 
originated in the Middle East and now grow worldwide in temperate and tropical regions (Fleming, 2000). Cannabis spp. contain several bioactive constituents known as cannabinoids. The best known are tetrahydrocannabinol (THC), cannabidiol and cannabinol. These compounds affect the itch pathway through cannabinoid receptors (van der Stelt et al., 2005). In humans, topical cannabinoid agonists attenuated histaminergic itch (Karsak et al., 2007) and uremic pruritus (Szepietowski et al., 2005). Systemic cannabinoids in the form of dronabinol have shown promising effects in management of cholestatic pruritus (Neff et al., 2002). In a study, endogenous cannabinoids downregulated mast cell activation (Facci et al., 1995; Ständer et al., 2008).

\section{Capsicum frutescens}

Capsicum frutescens $\mathrm{L}$. with the common name of Chile pepper (Family: Solanaceae) is an annual (perennial in the tropics) plant indigenous to Central America and is cultivated today in warmer regions of the world (Fleming, 2000). In a study, topical capsaicin $0.05 \%$ liniment showed some anti-pruritic potency in hemodialysis patients with pruritus. Itching, however, was significantly lowered in capsaicin-pretreated patients compared to controls (Weisshaar et al., 2003). In another study, uremic pruritus was successfully treated with capsacin (Neess et al., 2000). Two trials showed that topical administration of $0.025 \%$ capsaicin cream for 6 weeks is effective in treating psoriasis. The first study showed a significant decrease in scaling and erythema in 44 patients with moderate and severe psoriasis (Bernstein et al., 1986). The second was a randomized, vehicle-controlled, double-blind study on 197 psoriasis patients and demonstrated significant decrease in scaling, thickness, erythema, and pruritus (Ellis et al., 1993). In a double-blind study, capsaicin inhibited substance $P$, a peptide transmitter involved in pain transmission, cutaneous vasodilation, and the inflammatory process (Ellis et al., 1993). Capsaicin produced a hot sensation when applied to the skin which confers its anti-pruritic effects, activating Transient Receptor Potential Vanilloid 1 (TRPV1) which is the key in the various itch pathways (Wilson \& Bautista, 2014). Capsaicin should not be used for the treatment of the pruritus on face. It is contraindicated on injured skin (Ellis et al., 1993).

\section{Centella asiatica}

Centella asiatica (L.) Urban commonly named Centella or Gotu Kola (Family: Apiaceae) is a plant indigenous to southeast Asia and some regions of Africa and America (Fleming, 2000). In a study, antipruritic and anti-inflammatory effect of Centella extract in rats were investigated. Oral administration of Centella extract exhibited anti-pruritic activities (George et al., 2009).

\section{Cinnamomum camphora}

Cinnamomum camphora (L.) J. Presl. commonly known as Camphor tree, Camphor wood or Camphor laurel (Family: Lauraceae) is an evergreen tree indigenous to Vietnam and an extending from southern China to southern Japan (Fleming, 2000). Camphor is a terpene derived from distillating the wood of the Camphor tree which is topically used as analgesic and anti-pruritic agent. It affects itch sensation by activating and desensitizing the Transient Receptor Potential channel (TRP) V1 and A1 in vitro and in rats (Xu et al., 2005; Marsakova et $a l .$, 2012). This family of thermosensitive receptor channels is essential in itch perception. Substances with anti-pruritic activity that produce a heating or cooling effect on the skin seem to work at these receptors (Haught et al., 2008). In a study, patients reported that vaporizing the rub - containing menthol, camphor, and eucalyptus - had an effective antipruritic activity in epidermolysis bullosa. Furthermore, camphor together with menthol successfully treated hydroxyethyl starch-induced pruritus in one patient (Haught et al., 2008).

\section{Curcuma longa}

Curcuma longa L. with the common name of Turmeric (Family: Zingiberaceae) is a perennial plant indigenous to India and now is cultivated in tropical regions of Southeast Asia (Fleming, 2000). Turmeric has been used topically to treat a variety of dermatologic conditions due to its antimicrobial and anti-inflammatory properties (Luthra et al., 2001; Velayudhan et al., 2012; Prasad, 2013; Prasad et al., 2014). In a double-blind placebo-controlled trial, significant reduction of pruritus scores was demonstrated in patients with uremic pruritus. Orally prescribed turmeric reduced high-sensitivity Creactive protein (hs-CRP) levels with no side effect (Pakfetrat et al., 2014). In a randomized controlled trial, curcumin, the major bioactive constituent of turmeric, improved itch and decreased hs-CRP and IL-8 levels in patients with chronic pruritus due to 
sulfur mustard exposure (Panahi et al., 2012a; Panahi et al., 2012b). In psoriasis, oral curcumin together with topical corticosteroids produced greater reduction of disease burden and IL-22 level compared to topical corticosteroids alone (Antiga et al., 2015).

\section{Diospyros kaki}

Diospyros kaki Thunberg. commonly named Persimmon (Family: Ebenaceae) is a tree similar in shape to an apple tree, native to China, Korea, and Japan. The fruit is sweet, slightly tangy with a soft or fibrous texture (Fewtrell \& Gomperts, 1977). In a study, it induced a significant alleviation of dermatitis, scratching behavior through reducing the serum level of $\mathrm{IgE}$ in atopic dermatitis mice model (Kotani et al., 2000). A flavonol compound, kaempferol, which has been identified in the hot water extract of persimmon leaves, has been reported to inhibit antigen-induced histamine secretion from rat mast cells (Fewtrell \& Gomperts, 1977; Chakravarty, 1980; Amellal et al., 1985).

\section{Fumaria spp.}

Fumaria spp. include F.officinalis L., F.vaillantii Loisel (syn: Fumaria indica), F.parviflora L. with the common name of Fumitory (Family: Fumariaceae; Papaveraceae) are herbaceous annual flowering plants, which grow in various parts of the world. The aerial part of Fumitory due to its chemical content including benzylisoquinoline alkaloids, flavonoids and organic acids especially fumaric acid have been used for the treatment of pruritus. F. parviflora (FP) significantly decreased the severity of uremic pruritus (UP) in hemodialysis patients. The maximum effect of FP was recorded after week 4. This study demonstrated significant decrease in IFN- $\gamma$ level in patients who received FP compared to those who received placebo (Akrami et al., 2017). The results of clinical trial comparing the efficacy and safety of $F$. vaillantii with cetirizine showed no significant difference in Urtcaria Acitivity Score (UAS) and Chronic Urticaria Quality of Life Questionnaire (CUQ2oL) between two groups of patients after 4 weeks of treatment; however Follow up of patients one month after discontinuation of treatment demonstrated significant reduction of UAS as well as better quality of life score in Fumaria group compared to Cetirizine. About adverse events, the incidence of somnolence in the Fumaria group was significantly lower than in the Cetirizine group (Eghbalian et al., 2018). In a randomized double- blind placebo controlled clinical trial, alcoholic $F$. parviflora extract produced improvement in all types of hand eczema in patients compared to placebo (Jowkar et al., 2011). In a study, it was demonstrated that fumaric acid esters (FAEs) mainly monomethyl fumarate (MMF) present in Fumitory had immunomodulatory, anti-inflammatory, and antioxidative effects and could inhibit proinflammatory activity of human C-reactive protein (CRP) in rats. In an in vitro study MMF lowered IFN- $\gamma$ plasma level (de Jong et al., 1996). In an in vitro study, it was demonstrated that psoriasis can be treated successfully with FAEs through reducing production of IFN- $\gamma$ (Litjens et al., 2004).

\section{Glycyrrhiza glabra}

Glycyrrhiza glabra L. commonly known as Liquorice or Licorice (Family: Fabaceae) is an herbaceous perennial plant indigenous to southern Europe and southwest Asia and now is found in different regions (Fleming, 2000). In a double-blind, vehiclecontrolled phase II trial, a standardized extract of Licorice in the form of $1 \%$ and $2 \%$ gels were used for treatment of $\mathrm{AD}$ (30 patients in each group). The $2 \%$ licorice gel was more effective than $1 \%$ gel and the vehicle in reducing the symptoms of erythema, edema, and itching after two weeks of treatment (Saeedi et al., 2003). In a study, glycyrrhizin inhibited prostaglandin E2 production by activated peritoneal macrophages from rats (Ohuchi et al., 1981).

\section{Impatiens balsamina}

Impatiens balsamina L. commonly named Garden balsam, Garden jewelweed or touch-me-not (Family: Balsaminaceae) is a glabrous, fleshy annual plant grows mostly in the mountainous and tropical regions of Asia and Africa (Fleming, 2000). The effects of hydroethanolic extract from the petals of Garden balsam and its bioactive compounds were examined on chronic and serious pruritus of $\mathrm{NC}$ mice with established dermatitis. The extract significantly inhibited serious scratching behavior when administered i.v. $1 \mathrm{~h}$ before, or p.o. $24 \mathrm{~h}$ before the measurement. Kaempferol 3-rutinoside and 2hydroxy-1,4-naphthoquinone (lawsone) isolated from Garden balsam also inhibited scratching behavior in the NC mouse with established dermatitis. Protective role of Garden balsam extract against scratching behavior when administered orally to 4-week-old NC mice with no symptoms until 13 weeks of age was also reported (Oku \& Ishiguro, 2001). Kaempferol 
and Kaempferol-3-glucoside (astragalin) from the white petals of Garden balsam exhibited anti-pruritic effect on dextran T40-evoked scratching behavior in mice (Ishiguro \& Oku, 1997).

\section{Lecythis pisonis}

Lecythis pisonis Camb. with the common name of Sapucaia (Family: Lecythidaceae) is a large tree widely distributed in the Amazon region. Leaves of Sapucaia have been used for the treatment of pruritus. Pretreatment of mice with ethanol extract of Sapucaia markedly inhibited scratching behavior induced by compound 48/80. Pentacyclic triterpenes including ursolic and oleanolic acids seems to plat the major role in anti-pruritic activity of Sapucaia. Anti-pruritic activity of this herb was through its stabilizing action on mast cell membrane (Saeedi et al., 2003).

\section{Matricaria chamomilla}

Matricaria chamomilla L. (syn: Matricaria recutita L.) commonly known as Chamomile (Family: Asteraceae) is an annual plant indigenous to Europe and northwest Asia (Fleming, 2000). Different studies have demonstrated that chamomile relieved histaminergic pruritus (Kobayashi et al., 2003; Kobayashi et al., 2005; Chandrashekhar et al., 2011) and inhibited anaphylaxis in type I hypersensitivity allergy models in mice (Chandrashekhar et al., 2011). Chamomile significantly reduced scratching behavior induced by compound $48 / 80$ and the effect was more distinct when chamomile was given concomitantly with a first-generation antihistamine. In a mouse model of atopic dermatitis, topical application of chamomile reduced scratching behavior and serum IgE level (Lee et al., 2010). Apigenin, one of the major components of Chamomile, reduced NF- $\kappa \mathrm{B}$ and IL-4 expressions as well as IgE serum level in mice. Bisabolol, another active compound of chamomile, has been demonstrated to inhibit activation of inflammatory markers including NF- $\kappa B$, TNF- $\alpha$ and IL-6 in murine models (Kim et al., 2011; Maurya et al., 2014).

\section{Mentha $x$ piperita}

Mentha $x$ piperita L. (syn: Mentha balsamea Wild.) commonly known as Peppermint (Family: Labiateae; Lamiaceae) is a perennial plant indigenous to Europe and the Middle East. The plant has widely spread and cultivated in many regions of the world (Patel et al., 2007). In a randomized triple-blind clinical trial, external use of Peppermint oil twice a day during two weeks, significantly decreased the severity of skin itching in pregnant women with pruritus gravidarum compared to placebo group (Akhavan-Amjadi et al., 2012). Topical application of peppermint oil created a cooling sensation and activated the thermosensitive TRPM 8 and TRPA1, which resulted in inhibited itch signal transmission (Fröhlich et al., 2009). Relieving effect on pruritus has been demonstrated in conditions including lichen amyloidosis and epidermolysis bullosa (Fröhlich et al., 2009; Danial et al., 2015). Active component of Peppermint is menthol, a cyclic terpene alcohol that is responsible for characteristic smell od Mentha genus (Jonathan et al., 2013). In a study, the mixture of $1 \%$ phenol and $1 \%$ menthol significantly alleviated mustard gasinduced pruritus in chemical warfare-injured patients compared to placebo (Panahi et al., 2007). Moreover, a topical lotion containing $0.5 \%$ menthol and $0.5 \%$ camphor was beneficial in mustard gas-induced pruritus. It caused a rapid relief of the symptoms during attacks and decreased the frequency of attacks with topical application oof 3 times daily (Haught $e t$ al., 2008).

\section{Oenothera biennis}

Oenothera biennis L. commonly known as Evening primrose or Evening star (Family: Onagraceae) is a biennial plant originally indigenous to North America and is now naturalized throughout most of Europe and parts of Asia (Fleming, 2000). The oil extracted from seeds is rich in poly unsaturated fatty acids especially $\gamma$-linolenic acid (GLA). In a double-blind study, 9 and 7 dialysis patients were randomly assigned to receive either Evening primrose oil (EPO) or linoleic acid (LA) (2 g per day) for 6 weeks and the symptom of pruritus were assessed by questionnaire. The patients given EPO exhibited a significant increase in plasma dihomo- $\gamma$-linolenic acid. They also showed a significant improvement in pruritus than those given LA (Yoshimoto-Furuie et al., 1999). A meta-analysis of 26 clinical studies including 1207 patients indicated that Evening primrose oil has a beneficial effect on pruritus that becomes apparent between 4 and 8 weeks after beginning of treatment (Morse \& Clough, 2006).

\section{Panax ginseng}

Panax ginseng C.A. MEYER with common name of Ginseng (Family: Araliaceae) is a perennial plant indigenous to China and is now cultivated in eastern Asia and Russia (Fleming, 2000). The roots are the medicinal part of the plant and usually harvested when it is five or six years old. Ginsenosides are 
triterpene saponins of the root with various biological activities, including anti-allergic activity (Choo et al., 2003; Park et al., 2003). The anti-allergic activitiy of ginsenosides is due to compound $\mathrm{K}$ produced during the biotransformation of ginsenosides by human intestinal microflora. Ginsenoside Rb1, a triterpene saponin isolated fron Ginseng, ameliorated scratching behavior induced by compound $48 / 80$ in ICR mice (Shin \& Kim, 2005). In a study, Korean Red Ginseng (KRG) and ginsenosides exhibited anti-inflammatory and anti-allergic effects against atopic dermatitis by inhibiting $\mathrm{T}_{\mathrm{h}} 2$ mediated inflammation as well as by diminishing the itching sensation (Lee \& Cho, 2017).

\section{Platycodon grandiflorum}

Platycodon grandiflorum (grandiflorus) (Jacq.) A. DC. commonly known as Platycodon, Balloonflower, or Chinese bellflower (Family: Campanulaceae) is a perennial plant indigenous to eastern Asia and Siberia (Fleming, 2000). The fermented extract of Platycodon Markedly reduced the serum level of $\mathrm{IgE}$ and its anti-scratching behavioral effect was more potent than Platycodon extract. This result indicated that anti-pruritic effect of Platycodon was enhanced by fermentation (with Saccharomyces cerevisae) (Ha et al., 2014).

\section{Quercus acutissima}

Quercus acutissima Carruth. commonly known as Sawtooth oak (Family: Fagaceae) is an Asian species of Oak tree native to China, Korea, Japan, Indochina and the Himalayas. Methanolic extracts of the plant bark showed anti-pruritic activity in cutaneous diseases induced by substance $\mathrm{P}$ in mice. When administered orally 30 min before SP injection, the methanol extract inhibited SP-induced itch-scratch response without affecting locomotor activity (Tohda et al., 2000).

\section{Rumex Japonicus}

Rumex Japonicus Houtt. with the common name of Goat-hoof, or Japanese Dock (Family: Polygonaceae) is a perennial herb native to Eastern Asian countries. Administration of Goat-hoof in NC/Nga mice for 42 days caused remarkable reduction in scratching behavior and IgE and IL-4 serum levels (Lee et al., 2006).

\section{Saururus chinensis}

Saururus chinensis (Lour.) Baill. commonly named Saururus (Family: Saururaceae) is a perennial plant native to Korea. Oral administration of Saururus leaf extract to $\mathrm{NC} / \mathrm{Nga}$ mice for 8 weeks markedly suppressed development of AD-like skin lesions and reduced scratching behavior and IgE serum level. These results modulating the $\mathrm{T}_{\mathrm{h}} 1 / \mathrm{T}_{\mathrm{h}} 2$ imbalance by Saururus (Choi et al., 2008).

\section{Vaccinium myrtillus}

Vaccinium myrtillus L. with the common name of Bilberry (Family: Ericaceae) is a deciduous, dwarf shrub common to central and northern Europe, Asia and North America (Fleming, 2000). Three weeks oral administration of Bilberry extract alleviated pruritus and scratching behavior in a mouse model of chronic allergic contact dermatitis (Yamaura et al., 2011). Moreover, anthocyanin-rich Bilberry extract alleviated pruritus, suggesting that the anthocyanins are the main active components. The inhibitory effect of Bilberry anthocyanins on chronic pruritus of experimental dermatitis might be through inhibition of mast cell degranulation (Yamaura et al., 2012).

\section{Vanillosmopsis arborea}

Vanillosmopsis arborea Baker commonly known as Candeeiro (Family: Asteraceae) is a small tree grows in Brazil. Its wood has a strong odor of chamomile and burns easily with a strong flame (Matos et al., 1988). Essential oil of Candeeiro, which is rich in (-)$\alpha$-bisabolol (a sesquiterpene alcohol), inhibited histamine-induced scratching behavior immediately after application in histamine-induced mice model of pruritus (Campos et al., 2014; da Costa, 2015).

\section{CONCLUSION}

Itch or pruritus is a distressing and uncomfortable sensation of the skin that provokes the desire to scratch. Pruritus can sometimes be disabling, and extremely difficult to be managed effectively. Despite to various systemic and topical conventional drugs used for management of pruritis, the necessity for identifying more efficacious drugs with lower rate of adverse events is still obvious. Herbal therapy for pruritic diseases has been used for thousands of years. In the present study, we introduced some medicinal plants and their bioactive components for the management of pruritus with the prospect of further investigation on these herbs as promising anti-pruritic agents. Although many herbs are listed in the management of pruritus, few have actually been investigated with well-designed clinical trials.

There were 23 human studies, 32 in vivo and only 6 in vitro studies which considered to be mentioned in this review. Among the human studies, medicinal plants including Avena sativa, Borago 
officinalis, Capsicum frutescens, Curcuma longa, Fumaria spp., Mentha x piperita and Oenothera biennis showed the best anti-pruritic activity. Among preclinical studies, Actinidia arguta, Amorphophallus konjac, Angelica sinensis, Betula platyphylla, Diospyros kaki, Impatiens balsamina, Lecythis pisonis, Matricaria chamomilla, Platycodon grandiflorum, Rumex Japonicus, Saururus chinensis and Vaccinium myrtillus showed remarkable activity in the management of pruritus.

Among different herbs mentioned in this review, Curcuma longa, and Fumaria spp. had the highest level of clinical evidence for their anti-pruritic effect through different mechanisms.

Bilberry anthocyanins, ginsenosides (triterpenoid saponins), avenanthramides, bradykinase, mannose-6-phosphate, acemannan, lupeol (a sterol), (-)$\alpha$-bisabolol, GLA ( $\Upsilon$-linolenic acid), cannabinol, cannabidiol, dronabinol, THC (tetrahydrocannabinol), capsaicin, camphor, curcumin, kaempferol, kaempferol 3-rutinoside, Kaempferol-3-glucoside (astragalin), 2hydroxy-1,4-naphthoquinone (lawsone), ursolic acid, oleanolic acid, apigenin, menthol, fumaric acid, MMF (monomethyl fumarate), glycyrrhetinic acid and glycyrrhizin were presented as the main bioactive components of medicinal plants which exhibited antipruritic property.

Anti-pruritic activity of the herbs and their bioactive constituents was mediated by different mechanisms including reduction of $\mathrm{IgE}$ serum level, suppressing the $\mathrm{T}_{\mathrm{h}} 2$ cellular response, reducing proinflammatory cytokines (IL-4, Il-6, IL-8, IFN- $\gamma$, TNF-a), decreasing or suppressing the expression of substance $\mathrm{P}$, reducing the expressions of NF- $\mathrm{B}$, inhibiting prostaglandin E2 production, activating TRPV1, reducing hs-CRP, activating the thermosensitive TRPM8 and TRPA1, and stabilizing action on mast cell and inhibiting the release of histamine from them.

Result obtained from the clinical trials evaluating anti-pruritic effects of the herbs and their bioactive constituents, showed that there is a need for conducting further well-designed human studies with larger sample size and longer follow-up period to confirm the efficacy of medicinal plants and their bioactive components in the management of pruritus.

\section{ACKNOWLEDGEMENTS}

This work was student thesis and supported by a grant from Traditional Medicine and Pharmacy Research Control, Faculty of Pharmacy, Tehran University of Medical Sciences numbers No 94-03-
96-30194 \& No 95-03-96-32757.

\section{REFERENCES}

Akhavan-Amjadi M, Mojab F, Kamranpour SB. 2012. The effect of peppermint oil on symptomatic treatment of pruritus in pregnant women. Iran J Pharm Res 11: 1073 - 1077.

Akrami R, Hashempur MH, Tavakoli A, Nimrouzi M, Sayadi M, Roodaki M, Roozbeh J, Faridi P. 2017. Effects of Fumaria parviflora L on uremic pruritus in hemodialysis patients: a randomized, double-blind, placebo-controlled trial. Jundishapur J Nat Pharm Prod 12: e39744.

Alakurtti S, Mäkelä T, Koskimies S, Yli-Kauhaluoma J. 2006. Pharmacological properties of the ubiquitous natural product betulin. Eur J Pharm Sci 29: 1 - 13.

Amellal M, Bronner C, Briancon F, Haag M, Anton R, Landry Y. 1985. Inhibition of mast cell histamine release by flavonoids and biflavonoids. Planta Med 51: 16 - 20.

Antiga E, Bonciolini V, Volpi W, Del Bianco E, Caproni M. 2015. Oral curcumin (Meriva) is effective as an adjuvant treatment and is able to reduce IL-22 serum levels in patients with psoriasis vulgaris. BioMed Res Int Volume 2015, Article ID 283634, 7 pages.

Bernstein JE, Parish LC, Rapaport M, Rosenbaum MM, Roenigk Jr HH. 1986. Effects of topically applied capsaicin on moderate and severe psoriasis vulgaris. J Am Acad Dermatol 15: 504 - 507.

Bina F, Soleymani S, Toliat T, Hajimahmoodi M, Tabarrai M, Abdollahi M, Rahimi R. 2018. Plant-derived medicines for treatment of endometriosis: A comprehensive review of molecular mechanisms. Pharmacol Res 139: 76-90.

Campos A, Leite L, de Oliveira Leite G, Barros A, de Menezes I, da Costa J. 2014. Anti-pruritic and central antinociceptive effects of Vanillosmopsis Arborea essential oil in mice. Basic Clin Pharmacol Toxicol 115: 101.

Chakravarty N. 1980. The role of plasma membrane $\mathrm{Ca}^{++}-\mathrm{Mg}^{++} \quad$ activated adenosine triphosphatase of rat mast cells on histamine release. Basic Clin Pharmacol Toxicol 47: $223-235$.

Chandrashekhar VM, Halagali KS, Nidavani RB, Shalavadi MH, Biradar BS, Biswas D, 
Muchchandi IS. 2011. Anti-allergic activity of German chamomile (Matricaria recutita L.) in mast cell mediated allergy model. J Ethnopharmacol 137: 336 - 340.

Choi S, Chung MH, 2003. A review on the relationship between Aloe vera components and their biologic effects. Seminars in integrative medicine, Saunders (Elsevier), USA.

Choi MS, Kim EC, Lee HS, Kim SK, Choi HM, Park JH, Han JB, An HJ, Um JY, Kim HM, Han AR, Hong MC, Bae H, Min BI. 2008. Inhibitory effects of Saururus chinensis (Lour.) Baill on the development of atopic dermatitis-like skin lesions in NC/Nga mice. Biol Pharm Bull 31: 51 - 56.

Choo MK, Park EK, Han MJ, Kim DH. 2003. Antiallergic activity of ginseng and its ginsenosides. Planta Med 69: 518 - 522.

da Costa JGM. 2015. The essential oil from Vanillosmopsis arborea Baker (Asteraceae) presents antinociceptive, anti-inflammatory, and sedative effects. Int J Green Pharm 9: $138-142$.

Dalgard F, Svensson Å, Holm J, Sundby J. 2004. Self-reported skin morbidity in Oslo. Associations with sociodemographic factors among adults in a cross-sectional study. $\mathbf{B r} \mathbf{~}$ Dermatol 151: 452 - 457.

Dalgard F, Dawn AG, Yosipovitch G. 2007. Are itch and chronic pain associated in adults? Results of a large population survey in Norway. Dermatology 214: 305 - 309.

Danial C, Adeduntan R, Gorell ES, Lucky AW, Paller AS, Bruckner AL, Pope E, Morel KD, Levy ML, Li S, Gilmore ES, Lane AT. 2015. Evaluation of treatments for pruritus in epidermolysis bullosa. Pediatr Dermatol 32: $628-634$.

de Jong R, Bezemer AC, Zomerdijk TP, van de Pouw-Kraan T, Ottenhoff TH, Nibbering PH. 1996. Selective stimulation of $\mathrm{T}$ helper 2 cytokine responses by the anti-psoriasis agent monomethylfumarate. Eur J Immunol 26: 2067 - 2074.

Eghbalian F, Esmaili N, Karimi M, Mohajerani F, Rahimi R, Atyabi A, Tohidinik HR, Shirbeigi L. 2018. Comparison of the efficacy and tolerability of an oral dosage form made from Fumaria vaillantii versus cetirizinein management of chronic urticaria: A single blind, randomized, clinical trial. Biomed Res
Ther 5: 2389 - 2401.

Ellis CN, Berberian B, Sulica VI, Dodd WA, Jarratt MT, Katz HI, Prawer S, Krueger G, Rex IH Jr, Wolf JE. 1993. A double-blind evaluation of topical capsaicin in pruritic psoriasis. $\mathbf{J}$ Am Acad Dermatol 29: 438 - 442.

Facci L, Dal Toso R, Romanello S, Buriani A, Skaper S, Leon A. 1995. Mast cells express a peripheral cannabinoid receptor with differential sensitivity to anandamide and palmitoylethanolamide. Proc Natl Acad Sci 92: $3376-3380$.

Farzaei MH, Shams-Ardekani MR, Abbasabadi Z, Rahimi R. 2013. Scientific evaluation of edible fruits and spices used for the treatment of peptic ulcer in traditional Iranian medicine. ISRN Gastroenterol 2013.

Farzaei M, Bahramsoltani R, Rahimi R, Abbasabadi F, Abdollahi M. 2016a. A systematic review of plant-derived natural compounds for anxiety disorders. Curr Top Med Chem 16: 1924 - 1942.

Farzaei M, Bahramsoltani R, Rahimi R. 2016b. Phytochemicals as adjunctive with conventional anticancer therapies. Curr Pharm Des 22: 4201 - 4218.

Fewtrell C, Gomperts B. 1977. Effect of flavone inhibitors of transport ATPases on histamine secretion from rat mast cells. Nature 265: $635-636$.

Finberg MJ, Muntingh GL, van Rensburg C. 2015. A comparison of the leaf gel extracts of Aloe ferox and Aloe vera in the topical treatment of atopic dermatitis in Balb/c mice. Inflammopharmacology 23: 337 - 341.

Fleming T. 2000. PDR for herbal medicines. Medical Economics: New Jersey, USA.

Fröhlich M, Enk A, Diepgen TL, Weisshaar E. 2009. Successful treatment of therapy-resistant pruritus in lichen amyloidosis with menthol. Acta Derm Venereol 89: 524 - 526.

George M, Joseph L, Ramaswamy. 2009. Antiallergic, anti-pruritic, and anti-inflammatory activities of Centella asiatica extracts. Afr $\mathbf{J}$ Tradit Complement Altern Med 6: 554 559.

Goyal S, Aggarwal K, Gupta M. 2014. Managing pruritus: A therapeutic challenge. Indo Am J Pharm Res 4: 2557 - 2562.

Ha M, Kim JW, Lee SW, Chun HS, Cho YS, Shin YW. 2014. Anti-pruritic effect of ethanol extracts from Platycodon grandiflorum and 
its fermented production in Scratching Behavior Mouse Models. Korea J Herbol 29: $165-173$.

Haught JM, Jukic DM, English JC. 2008. Hydroxyethyl starch-induced pruritus relieved by a combination of menthol and camphor. J Am Acad Dermatol 59: 151 153.

Horrobin DF. 2000. Essential fatty acid metabolism and its modification in atopic eczema. Am J Clin Nutr 71: 367 - 372.

Ikoma A, Steinhoff M, Ständer S, Yosipovitch G, Schmelz M. 2006. The neurobiology of itch. Nat Rev Neurosci 7: 535 - 547.

Ishiguro K, Oku H. 1997. Anti-pruritic effect of flavonol and 1,4-naphthoquinone derivatives from Impatiens balsamina L. Phytother Res 11: 343 - 347.

Jiang S, Tsumuro T, Takubo M, Fujii Y, Kamei C. 2005. Anti-pruritic and antierythema effects of ascomycete Bulgaria inquinans extract in ICR mice. Biol Pharm Bull 28: 2197 - 2200.

Jonathan YX, Li L, Hasan R, Zhang X. 2013. Excitation and modulation of TRPA1, TRPV1, and TRPM8 channel-expressing sensory neurons by the pruritogen chloroquine. J Biol Chem 288: 12818 12827

Jowkar F, Jamshidzadeh A, Yazdi AM, Pasalar M. 2011. The effects of Fumaria parviflora L extract on chronic hand eczema: a randomized double-blind placebo controlled clinical trial. Iran Red Crescent Med J 13: $824-828$.

Kanehara S, Ohtani T, Uede K, Furukawa F. 2007. Clinical effects of undershirts coated with Borage oil on children with atopic dermatitis: A double-blind, placebo-controlled clinical trial. J Dermatol 34: 811 - 815.

Karsak M, Gaffal E, Date R, Wang-Eckhardt L, Rehnelt J, Petrosino S, Starowicz K, Steuder R, Schlicker E, Cravatt B, Mechoulam R, Buettner R, Werner S, Di Marzo V, Tüting T, Zimmer A. 2007. Attenuation of allergic contact dermatitis through the endocannabinoid system. Science 316: 1494 $-1497$.

Kim EC, Lee HS, Kim SK, Choi MS, Lee S, Han JB, An HJ, Um JY, Kim HM, Lee NY, Bae H, Min BI. 2008. The bark of Betula platyphylla var. japonica inhibits the development of atopic dermatitis-like skin lesions in NC/Nga mice. J Ethnopharmacol 116: 270 - 278.

Kim J, Lee Is, Park S, Choue R. 2010. Effects of Scutellariae radix and Aloe vera gel extracts on immunoglobulin $\mathrm{E}$ and cytokine levels in atopic dermatitis $\mathrm{NC/Nga}$ mice. J Ethnopharmacol 132: 529 - 532.

Kim S, Jung E, Kim JH, Park YH, Lee J, Park D. 2011. Inhibitory effects of (-)- $\alpha$-bisabolol on LPS-induced inflammatory response in RAW264.7 macrophages. Food Chem Toxicol 49: 2580 - 2585.

Kobayashi Y, Nakano Y, Inayama K, Sakai A, Kamiya T. 2003. Dietary intake of the flower extracts of German chamomile (Matricaria recutita L.) inhibited compound 48/80induced itch-scratch responses in mice. Phytomedicine 10: 657 - 664.

Kobayashi Y, Takahashi R, Ogino F. 2005. Antipruritic effect of the single oral administration of German chamomile flower extract and its combined effect with antiallergic agents in ddY mice. J Ethnopharmacol 101: 308 - 312.

Kotani M, Matsumoto M, Fujita A, Higa S, Wang W, Suemura M, Kishimoto T, Tanaka T. 2000. Persimmon leaf extract and astragalin inhibit development of dermatitis and IgE elevation in NC/Nga mice. J Allergy Clin Immunol 106: 159 - 166.

Lee HS, Kim SK, Han JB, Choi HM, Park JH, Kim EC, Choi MS, An HJ, Um JY, Kim HM, Min BI. 2006. Inhibitory effects of Rumex japonicus Houtt. on the development of atopic dermatitis-like skin lesions in $\mathrm{NC} / \mathrm{Nga}$ mice. Br J Dermatol 155: 33 - 38.

Lee SH, Heo Y, Kim YC. 2010. Effect of German chamomile oil application on alleviating atopic dermatitis-like immune alterations in mice. J Vet Sci 11: 35 - 41.

Lee J, Choi YY, Kim MH, Han JM, Lee JE, Kim EH, Hong J, Kim J, Yang WM. 2016. Topical application of Angelica sinensis improves pruritus and skin inflammation in mice with atopic dermatitis-like symptoms. J Med Food 19: 98 - 105.

Lee HJ, Cho SH. 2017. Therapeutic effects of Korean red ginseng extract in a murine model of atopic dermatitis: anti-pruritic and antiinflammatory mechanism. J Korean Med Sci 32: 679 - 687.

Litjens NH, Rademaker M, Ravensbergen B, Rea D, van der Plas MJ, Thio B, Walding A, van 
Dissel JT, Nibbering PH. 2004. Monomethylfumarate affects polarization of monocyte-derived dendritic cells resulting in down-regulated $T_{h} 1$ lymphocyte responses. Eur J Immunol 34: 565 - 575.

Luthra PM, Singh R, Chandra R. 2001. Therapeutic uses of Curcuma longa (turmeric). Indian $\mathbf{J}$ Clin Biochem 16: 153 - 160.

Marsakova L, Touska F, Krusek J, Vlachova V. 2012. Pore helix domain is critical to camphor sensitivity of transient receptor potential vanilloid 1 channel. Anesthesiology 116: 903 - 917.

Matos MEO, De Sousa MP, Matos FJA, Craveiro AA. 1988. Sesquiterpenes from Vanillosmopsis arborea. J Nat Prod 51: 780 $-782$.

Matterne U, Apfelbacher CJ, Loerbroks A, Schwarzer T, Büttner M, Ofenloch R, Diepgen TL, Weisshaar E. 2011. Prevalence, correlates and characteristics of chronic pruritus: a population-based cross-sectional study. Acta Derm Venereol 91: 674 - 679.

Maurya SK, Seth A. 2014. Potential medicinal plants and traditional Ayurvedic approach towards urticaria: an allergic skin disorder. Int J Pharm Pharm Sci 6: 172 - 177.

Maurya AK, Singh M, Dubey V, Srivastava S, Luqman S, Bawankule DU. 2014. $\alpha-(-)-$ bisabolol reduces pro-inflammatory cytokine production and ameliorates skin inflammation. Curr Pharm Biotechnol 15: $173-181$.

Mobli M, Qaraaty M, Amin G, Haririan I, Hajimahmoodi M, Rahimi R. 2015. Scientific evaluation of medicinal plants used for the treatment of abnormal uterine bleeding by Avicenna. Arch Gynecol Obstet 292: 21 35.

Morse N, Clough P. 2006. A meta-analysis of randomized, placebo-controlled clinical trials of Efamol® Evening primrose oil in atopic eczema. Where do we go from here in light of more recent discoveries? Curr Pharm Biotechnol 7: 503 - 524.

Nebus J, Wallo W, Nystrand G, Chu M, Kurtz ES. 2006. Alleviating itchy, extra dry skin with an oatmeal, skin protectant lotion. J Am Acad Dermatol 54 (3).

Nebus J, Wallo W. 2008. Safety and tolerance of skin protectant lotions with Oat in patients with diabetes. J Am Acad Dermatol 58: AB70.
Neess CM, Hinrichs R, Dissemond J, Herrmann G, Poswig A, Servera-Llanras M, Hunzelmann $\mathrm{N}$, Brenneisen $\mathrm{P}$, Meewes C, Krieg T, Scharffetter-Kochanek K. 2000. Treatment of pruritus by capsaicin in a patient with pityriasis rubra pilaris receiving RE-PUVA therapy. Clin Exp Dermatol 25: 209 - 211.

Neff GW, O'Brien CB, Reddy KR, Bergasa NV, Regev A, Molina E, Amaro R, Rodriguez MJ, Chase V, Jeffers L, Schiff E. 2002. Preliminary observation with dronabinol in patients with intractable pruritus secondary to cholestatic liver disease. Am J Gastroenterol 97: 2117 - 2119.

Ohuchi K, Kamada Y, Levine L, Tsurufuji S. 1981. Glycyrrhizin inhibits prostaglandin E2 production by activated peritoneal macrophages from rats. Prostaglandins Med 7: 457 - 463.

Oku H, Ishiguro K. 2001. Anti-pruritic and antidermatitic effect of extract and compounds of Impatiens balsamina $\mathrm{L}$. in atopic dermatitis model NC mice. Phytother Res 15: 506 - 510.

Onishi N, Kawamoto S, Nishimura M, Nakano T, Aki T, Shigeta S, Shimizu H, Hashimoto K, Ono K. 2004. The ability of konjac-glucomannan to suppress spontaneously occurring dermatitis in NC/Nga mice depends upon the particle size. Biofactors 21: 163 - 166.

Onishi N, Kawamoto S, Nishimura M, Nakano T, Aki T, Shigeta S, Shimizu H, Hashimoto K, Ono K. 2005. A new immunomodulatory function of low-viscous konjac glucomannan with a small particle size: its oral intake suppresses spontaneously occurring dermatitis in $\mathrm{NC} / \mathrm{Nga}$ mice. Int Arch Allergy Immunol 136: 258 - 265.

Onishi N, Kawamoto S, Suzuki H, Santo H, Aki T, Shigeta S, Hashimoto K, Hide M, Ono K. 2007. Dietary pulverized konjac glucomannan suppresses scratching behavior and skin inflammatory immune responses in NC/Nga mice. Int Arch Allergy Immunol 144: 95 - 104.

Pakfetrat M, Basiri F, Malekmakan L, Roozbeh J 2014. Effects of turmeric on uremic pruritus in end stage renal disease patients: a doubleblind randomized clinical trial. J Nephrol 27: 203 - 207.

Panahi Y, Davoodi S, Khalili H, Dashti-Khavidaki S, 
Bigdeli M. 2007. Phenol and menthol in the treatment of chronic skin lesions following mustard gas exposure. Singapore Med J 48: $392-395$.

Panahi Y, Sahebkar A, Amiri M, Davoudi SM, Beiraghdar F, Hoseininejad SL, Kolivand M. 2012a. Improvement of sulphur mustardinduced chronic pruritus, quality of life and antioxidant status by curcumin: results of a randomised, double-blind, placebo-controlled trial. Br J Nutr 108: 1272 - 1279.

Panahi Y, Sahebkar A, Parvin S, Saadat A. 2012b. A randomized controlled trial on the antiinflammatory effects of curcumin in patients with chronic sulphur mustard-induced cutaneous complications. Ann Clin Biochem 49: 580 - 588.

Park EK, Choo MK, Kim EJ, Han MJ, Kim DH. 2003. Antiallergic activity of ginsenoside Rh2. Biol Pharm Bull 26: 1581 - 1584.

Park EJ, Kim B, Eo H, Park K, Kim Y, Lee HJ, Son M, Chang YS, Cho SH, Kim S, Jin M. 2005. Control of IgE and selective TH1 and TH2 cytokines by PG102 isolated from Actinidia arguta. J Allergy Clin Immunol 116: 1151 1157.

Park EJ, Park KC, Eo H, Seo J, Son M, Kim KH, Chang YS, Cho SH, Min KU, Jin M, Kim S. 2007. Suppression of spontaneous dermatitis in NC/Nga murine model by PG102 isolated from Actinidia arguta. J Invest Dermatol 127: 1154 - 1160.

Patel T, Ishiuji Y, Yosipovitch G. 2007. Menthol: a refreshing look at this ancient compound. J Am Acad Dermatol 57: 873 - 878.

Paul JC. 2015. Wound pruritus: pathophysiology and management. Chronic Wound Care Manag Res 2: 119 - 127.

Pogatzki-Zahn E, Marziniak M, Schneider G, Luger TA, Ständer S. 2008. Chronic pruritus: targets, mechanisms and future therapies. Drug News Perspect 21: 541 - 551.

Prasad D. 2013. Ethno-medicine and indigenous therapeutic practices of the Nicobarese of Katchal Island. J Andaman Sci Assoc 18: 96 $-101$.

Prasad S, Gupta SC, Tyagi AK, Aggarwal BB. 2014. Curcumin, a component of golden spice: from bedside to bench and back. Biotechnol Adv 32: 1053 - 1064.

Rea J, Newhouse ML, Halil T. 1976. Skin disease in Lambeth. A community study of prevalence and use of medical care. Br J Prev Soc Med 30: 107 - 114.

Reynertson KA, Garay M, Nebus J, Chon S, Kaur S, Mahmood K, Kizoulis M, Southall MD. 2015. Anti-inflammatory activities of colloidal oatmeal (Avena sativa) contribute to the effectiveness of oats in treatment of itch associated with dry, irritated skin. J Drugs Dermatol 14: 43 - 48.

Saeedi M, Morteza-Semnani K, Ghoreishi MR. 2003. The treatment of atopic dermatitis with licorice gel. J Dermatol Treat 14: 153 - 157.

Shahpiri Z, Bahramsoltani R, Farzaei MH, Farzaei F, Rahimi R. 2016. Phytochemicals as future drugs for Parkinson's disease: a comprehensive review. Rev Neurosci 27: $651-668$.

Shin YW, Kim DH. 2005. Anti-pruritic effect of ginsenoside $\mathrm{rb} 1$ and compound $\mathrm{K}$ in scratching behavior mouse models. J Pharmacol Sci 99: 83 - 88.

Šilhavý J, Zídek V, Mlejnek P, Landa V, Šimáková M, Strnad H, Oliyarnyk O, Škop V, Kazdová L, Kurtz T, Pravenec M. 2014. Fumaric acid esters can block pro-inflammatory actions of human CRP and ameliorate metabolic disturbances in transgenic spontaneously hypertensive rats. Plos One 9: e101906.

Ständer S, Steinhoff M, Schmelz M, Weisshaar E, Metze D, Luger T. 2003. Neurophysiology of pruritus: cutaneous elicitation of itch. Arch Dermatol 139: 1463 - 1470.

Ständer S, Weisshaar E, Mettang T, Szepietowski JC, Carstens E, Ikoma A, Bergasa NV, Gieler U, Misery L, Wallengren J, Darsow U, Streit M, Metze D, Luger TA, Greaves MW, Schmelz M, Yosipovitch G, Bernhard JD. 2007. Clinical classification of itch: a position paper of the International Forum for the Study of Itch. Acta Derm Venereol 87: 291 $-294$.

Ständer S, Weisshaar E, Luger TA. 2008. Neurophysiological and neurochemical basis of modern pruritus treatment. Exp Dermatol 17: 161 - 169.

Stewart JC, Morse PF, Moss M, Horrobin Dphil DF, Burton JL, Douglas WS, Gould DJ, Grattan CEH, Hindson TC, Anderson J, Jansen CT, Kennedy CTC, Lindskov R, Strong AMM. 1991. Treatment of severe and moderately severe atopic dermatitis with evening primrose oil (Epogam): a multi-centre study. 
J Nutr Environ Med 2: 9 - 15.

Syed TA, Ahmad SA, Holt AH, Ahmad SA, Ahmad SH, Afzal M. 1996. Management of psoriasis with Aloe vera extract in a hydrophilic cream: a placebo-controlled, double-blind study. Trop Med Int Health 1: 505 - 509.

Sur R, Nigam A, Grote D, Liebel F, Southall MD. 2008. Avenanthramides, polyphenols from oats, exhibit anti-inflammatory and anti-itch activity. Arch Dermatol Res 300: 569 - 574.

Szepietowski JC, Reich A, Szepietowski T. 2005. Emollients with endocannabinoids in the treatment of uremic pruritus: discussion of the therapeutic options. Ther Apheresis Dial 9: 277 - 279.

Tohda C, Kakihara Y, Komatsu K, Kuraishi Y. 2000. Inhibitory effects of methanol extracts of herbal medicines on substance P-induced itch-scratch response. Biol Pharm Bull 23: $599-601$.

Twycross R, Greaves MW, Handwerker H, Jones EA, Libretto SE, Szepietowski JC, Zylicz Z. 2003. Itch: scratching more than the surface. QJM 96: 7 - 26.

van der Stelt $M$, Trevisani $M$, Vellani V, De Petrocellis L, Schiano Moriello A, Campi B, McNaughton P, Geppetti P, Di Marzo V. 2005. Anandamide acts as an intracellular messenger amplifying $\mathrm{Ca}^{2+}$ influx via TRPV1 channels. EMBO J 24: 3026 - 3037.

Velayudhan K, Dikshit N, Nizar MA. 2012. Ethnobotany of turmeric (Curcuma longa L.). Indian J Tradit Know 11: 607 - 614.

Weisshaar E, Dunker N, Gollnick H. 2003. Topical capsaicin therapy in humans with hemodialysis-related pruritus. Neurosci Lett
345: 192 - 194.

Wilson SR, Bautista DM. 2014. Role of transient receptor potential channels in acute and chronic itch. In: Carstens E, Akiyama T. CRC Press Davis, California, USA.

$\mathrm{Xu} \mathrm{H}$, Blair NT, Clapham DE. 2005. Camphor activates and strongly desensitizes the transient receptor potential vanilloid subtype 1 channel in a vanilloid-independent mechanism. J Neurosci 25: 8924 - 8937.

Yagi A, Kabash A, Okamura N, Haraguchi H, Moustafa S, Khalifa T. 2002. Antioxidant, free radical scavenging and antiinflammatory effects of aloesin derivatives in Aloe vera. Planta Med 68: 957 - 960.

Yamaura K, Shimada M, Ueno K. 2011. Anthocyanins from bilberry (Vaccinium myrtillus L.) alleviate pruritus in a mouse model of chronic allergic contact dermatitis. Pharmacogn Res 3: 173 - 177.

Yamaura K, Ishiwatari M, Yamamoto M, Shimada M, Bi Y, Ueno K. 2012. Anthocyanins, but not anthocyanidins, from Bilberry (Vaccinium myrtillus L.) alleviate pruritus via inhibition of mast cell degranulation. J Food Sci 77: 262 - 267.

Yoshimoto-Furuie K, Yoshimoto K, Tanaka T, Saima S, Kikuchi Y, Shay J, Horrobin DF, Echizen H. 1999. Effects of oral supplementation with evening primrose oil for six weeks on plasma essential fatty acids and uremic skin symptoms in hemodialysis patients. Nephron 81: 151 - 159.

Yosipovitch G, Fleischer AB. 2003. Itch associated with skin disease. Am J Clin Dermatol 4: $617-622$. 